\title{
Origin of the lumbosacral plexus in Galea spixii (Wagler, 1831) (Rodentia, Caviidae)
}

\author{
Gleidson Benevides de Oliveira ${ }^{1 *}$ \\ Márcio Nogueira Rodrigues ${ }^{2}$ \\ Rejane dos Santos Sousa ${ }^{2}$ \\ Carlos Eduardo Bezerra de Moura ${ }^{3}$ \\ Maria Angélica Miglino ${ }^{2}$ \\ Moacir Franco de Oliveira ${ }^{1}$ \\ ${ }^{1}$ Department of Animal Science, Federal Rural University of the Semi-Arid \\ Avenida Francisco Mota, 572, Costa e Silva, CEP 59625-900, Mossoró - RN, Brazil \\ ${ }^{2}$ School of Veterinary Medicine and Animal Science, University of São Paulo, São Paulo - SP, Brazil \\ ${ }^{3}$ Department of Morphology, Federal University of Rio Grande do Norte, Natal - RN, Brazil \\ * Autor para correspondência \\ gleidson_benevides@hotmail.com
}

\section{Resumo}

Origem do plexo lombossacral em Galea spixii (Wagler, 1831) (Rodentia, Caviidae). O preá silvestre é um roedor pertencente à família Caviidae presente na região semiárida do Nordeste do Brasil. Foram utilizados 20 preás que vieram a óbito por causas naturais, obtidos no Centro de Multiplicação de Animais Silvestres (CEMAS) da Universidade Federal Rural do Semi-Árido (UFERSA). Os animais foram fixados em solução aquosa de formaldeído a $10 \%$ e, após $48 \mathrm{~h}$, foram dissecados para visualização do plexo. As relações topográficas do plexo lombossacral foram agrupadas em tabelas e, posteriormente, submetidas a análises estatísticas (teste do qui-quadrado com correção de Yates). O plexo lombossacral originou-se das raízes ventrais dos três últimos nervos lombares e dos três primeiros nervos sacrais, correspondendo a $65 \%$ dos animais estudados $\left(\mathrm{L}_{5} \mathrm{~L}_{6} \mathrm{~L}_{7} \mathrm{~S}_{1} \mathrm{~S}_{2} \mathrm{~S}_{3}\right)$. Originam-se do plexo os nervos: femoral, obturatório, isquiático, glúteo cranial, glúteo caudal e pudendo.

Palavras-chave: Anatomia; Nervos; Preá; Roedor; Sistema nervoso

\section{Abstract}

The yellow-toothed cavy is a rodent belonging to the Caviidae family that inhabits the semiarid region of northeastern Brazil. We used 20 cavies that had died of natural causes, obtained from the Reproduction Center of Wild Animals (CEMAS) of the Federal Rural University of the Semi-Arid (UFERSA). The animals were fixed in aqueous solution of $10 \%$ formaldehyde and, after 48 hours, they were dissected to visualize plexus. The topographic relations of the lumbosacral plexus were grouped into tables and then they underwent statistical analysis (chi-square test with Yates' correction). The lumbosacral plexus stemmed from the ventral roots of the last 3 lumbar nerves and the first 3 sacral nerves, corresponding to $65 \%$ of the animals under study $\left(\mathrm{L}_{5} \mathrm{~L}_{6} \mathrm{~L}_{7} \mathrm{~S}_{1} \mathrm{~S}_{2} \mathrm{~S}_{3}\right)$. These nerves stemmed from plexus: femoral, obturator, ischiatic, cranial gluteal, caudal gluteal, and pudendal. Key words: Anatomy; Nerves; Nervous system; Rodent; Yellow-toothed cavy 


\section{Introduction}

Galea spixii (Wagler, 1831) is a rodent belonging to the Caviidae family. It has a long and uniform body with dark gray dorsal surface and white belly. Its head and eyes are big, and its ears are small and rounded. It has crepuscular habit, lives in flocks and feeds on leaves, stems and fruit creepers, roots, tubers, and bark of young trees (MENDES, 1945).

Treaties on Veterinary Anatomy (DYCE et al., 2004; KÖNIG; LIEBICH, 2011) describe that the lumbar sacral plexus (Plexus lumbosacralis) derives from the union of the lumbar plexus (Plexus lumbalis) and plexus in the first sacral vertebra (Plexus sacralis), and it consists of ventral rami of the last lumbar and the first sacral nerves, having its origin on the spinal cord segments and distributing to the pelvic limbs and the viscera in the region.

The spinal nerves are connected to the spinal cord and their number varies among domestic species according to the number of vertebrae, which is variable, except in the neck, constant in all domestic mammals (GODINHO et al., 1985).

Data on the origin and distribution of nerves from the lumbar sacral plexus are relevant, because they provide useful information regarding clinical and surgical care, anesthesiology, and comparative anatomy. Having these aspects as a basis, Rondini et al. (2005) and Lacerda et al. (2006) conducted researches on chinchillas and cavies, respectively. Considering the same aspects, as well as the fact that information about the lumbar sacral plexus in yellow-toothed cavy is not available in the literature, we have chosen to address its origin and distribution.

\section{Material and Methods}

Twenty animals (10 males and 10 females), which died of natural causes, were used in this study. They were obtained from the Reproduction Center of Wild
Animals (CEMAS) of the Federal Rural University of the Semi-Arid (UFERSA), in Mossoró, Rio Grande do Norte, Brazil; it is licensed by the Brazilian Institute of Environment and Renewable Natural Resources (IBAMA) as a scientific breeding center (Registration 1478912).

The animals were perfused with a solution of $10 \%$ formaldehyde through the common carotid artery. After perfusion, they were immersed in a similar solution for conservation. After 48 hours, we started a dissection process by using naked eye or 10x magnifying glass $\left(\right.$ Zeiss $\left.^{\circledR}\right)$. The animals were placed in supine position and incised from the albicans line for removing cutaneous and subcutaneous tissue, with consequent abdominal and pelvic evisceration. The muscles psoas major, psoas minor, and iliacus were removed for identifying the roots of the plexus nerves, close to the intervertebral foramina. For an easier examination, as plexus was exposed, cotton soaked with $20 \%$ hydrogen peroxide was placed on it, remaining there for 12 hours.

Data were expressed by means of drawings and photographs and arranged into tables. After finishing dissection, data underwent chi-square test with Yates' correction $(\alpha=0.05)$.

\section{Results}

The dissection of the lumbar sacral plexus allowed us to observe that females under study had seven lumbar vertebrae. However, the number of sacral vertebrae among males varied from $3(70 \%)$ to $4(30 \%)$. It is noteworthy that in the latter case the nerve branches stemming from the fourth vertebra are not included in the formation of plexus.

The description of the origin of the lumbar sacral plexus was based on 4 types (type $\mathrm{I}-\mathrm{L}_{4} \mathrm{~L}_{5} \mathrm{~L}_{6} \mathrm{~L}_{7} \mathrm{~S}_{1} \mathrm{~S}_{2} \mathrm{~S}_{3}$, II $-\mathrm{L}_{5} \mathrm{~L}_{6} \mathrm{~L}_{7} \mathrm{~S}_{1} \mathrm{~S}_{2} \mathrm{~S}_{3}$, III $-\mathrm{L}_{5} \mathrm{~L}_{6} \mathrm{~L}_{7} \mathrm{~S}_{1} \mathrm{~S}_{2}$ and IV $-\mathrm{L}_{6} \mathrm{~L}_{7} \mathrm{~S}_{1} \mathrm{~S}_{2} \mathrm{~S}_{3}$ ); type II, the most common in the yellow-toothed cavy, occurred in 13 animals (65\%). Types I, III, and IV had a frequency of $5 \%, 20 \%$, and $10 \%$, respectively (Figures 1 to 4 ). 
FIGURE 1: Origin of the lumbar sacral plexus in the yellow-toothed cavy in $\mathrm{L}_{4}-\mathrm{S}_{3}$ (Type I). (A) Origin in situ and (B) schematic drawings. Scale: $1 \mathrm{~cm}$.

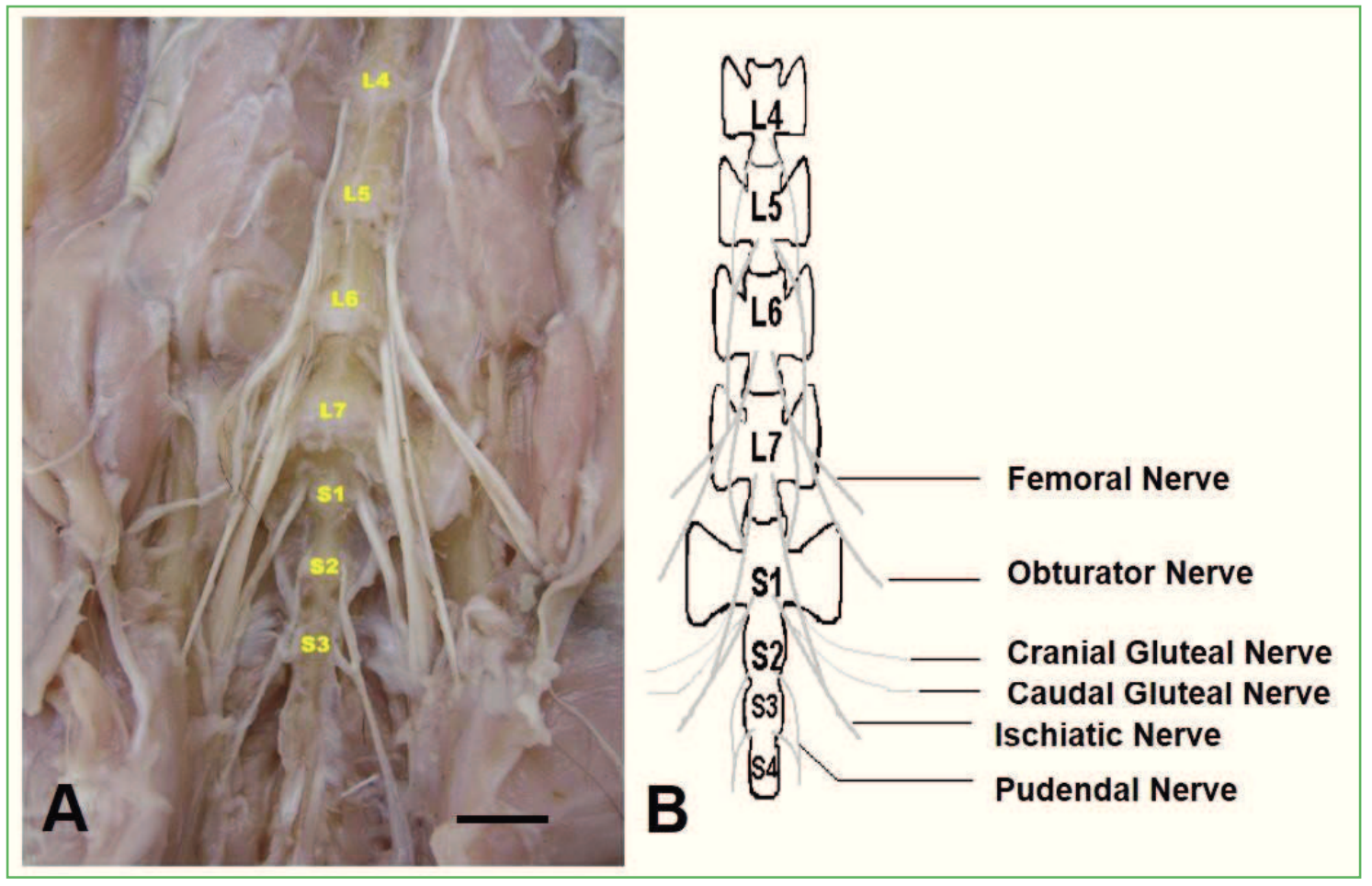

FIGURE 2: Origin of the lumbar sacral plexus in the yellow-toothed cavy in $\mathrm{L}_{5}-\mathrm{S}_{3}$ (Type II). (A) Origin in situ and (B) schematic drawings. Scale: $1 \mathrm{~cm}$.

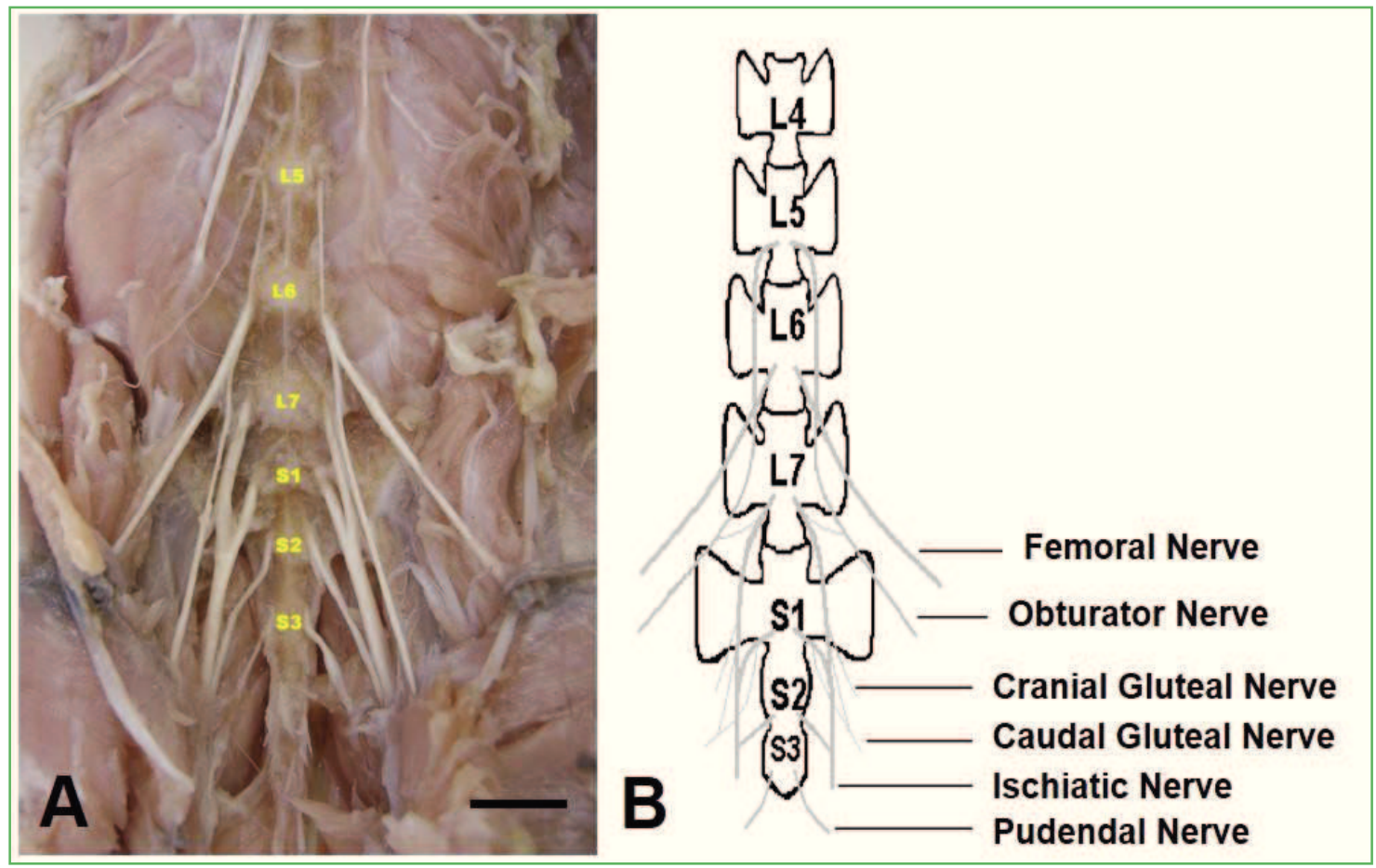


FIGURE 3: Origin of the lumbar sacral plexus in the yellow-toothed cavy in $\mathrm{L}_{5}-\mathrm{S}_{2}$ (Type III). (A) Origin in situ and (B) schematic drawings. Scale: $1 \mathrm{~cm}$.

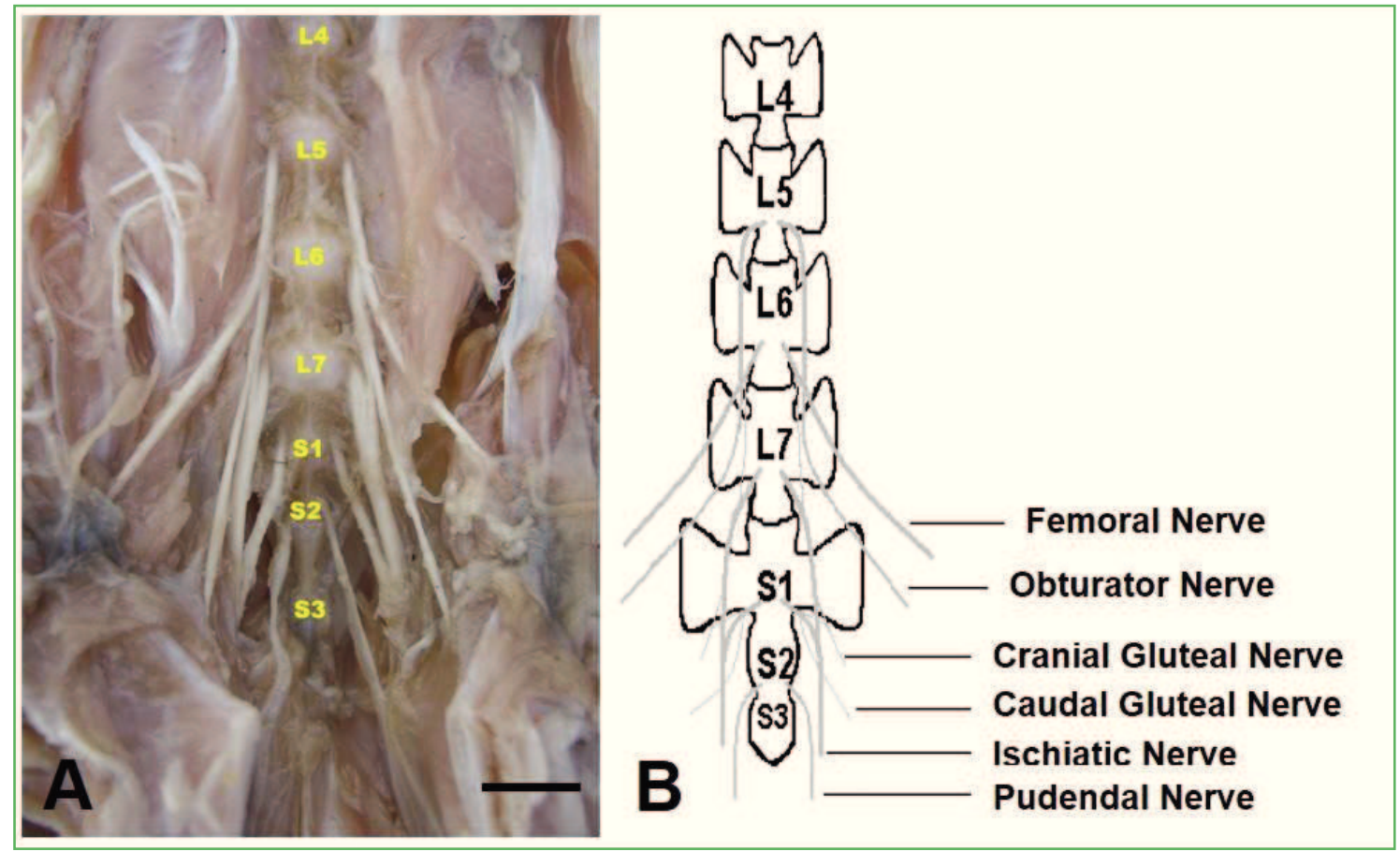

FIGURE 4: Origin of the lumbar sacral plexus in the yellow-toothed cavy in $\mathrm{L}_{6}-\mathrm{S}_{3}$ (Type IV). (A) Origin in situ and (B) schematic drawings. Scale: $1 \mathrm{~cm}$.
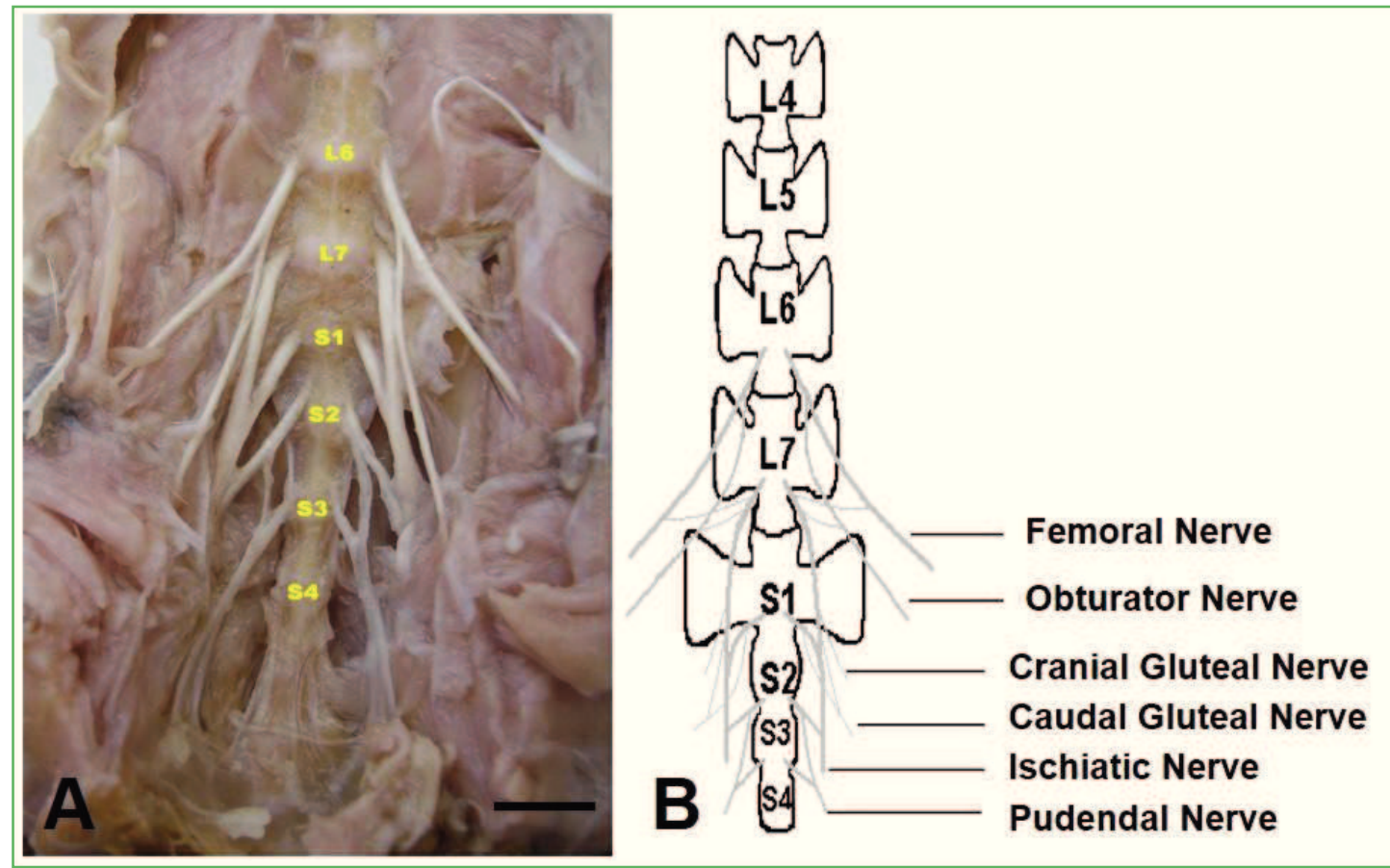
The analysis of the factor "origin of plexus" showed differences between sexes (Table 1), but there was a significant difference only in type III $(\mathrm{p}=0.02)$ when these data underwent statistical analysis.

TABLE 1: Origin of the lumbar sacral plexus in the yellowtoothed cavy according to sex. Males (M), Females (F).

\begin{tabular}{lccccc}
\hline \multirow{2}{*}{\multicolumn{1}{c}{ Type }} & \multicolumn{2}{c}{ Sex } & \multicolumn{2}{c}{$\begin{array}{c}\text { Relative } \\
\text { frequency (\%) }\end{array}$} & p \\
\cline { 2 - 5 } & $\mathbf{M}$ & $\mathbf{F}$ & $\mathbf{M}$ & $\mathbf{F}$ & \\
\hline Type I $-\mathrm{L}_{4} \mathrm{~L}_{5} \mathrm{~L}_{6} \mathrm{~L}_{7} \mathrm{~S}_{1} \mathrm{~S}_{2} \mathrm{~S}_{3}$ & 0 & 1 & $0.0 \%$ & $10.0 \%$ & 0.52 \\
Type II $-\mathrm{L}_{5} \mathrm{~L}_{6} \mathrm{~L}_{7} \mathrm{~S}_{1} \mathrm{~S}_{2} \mathrm{~S}_{3}$ & 8 & 5 & $80.0 \%$ & $50.0 \%$ & 0.55 \\
Type III $-\mathrm{L}_{5} \mathrm{~L}_{6} \mathrm{~L}_{7} \mathrm{~S}_{1} \mathrm{~S}_{2}$ & 0 & 4 & $0.0 \%$ & $40.0 \%$ & $\mathbf{0 . 0 2}$ \\
Type IV $-\mathrm{L}_{6} \mathrm{~L}_{7} \mathrm{~S}_{1} \mathrm{~S}_{2} \mathrm{~S}_{3}$ & 2 & 0 & $20.0 \%$ & $0.0 \%$ & 0.77 \\
\hline Total & 10 & 10 & $100 \%$ & $100 \%$ & - \\
\hline
\end{tabular}

* Chi-square test with Yates' correction $(\mathrm{p}<0.05)$.

The femoral, obturator, ischiatic, cranial gluteal, caudal gluteal, and pudendal nerves derive from the lumbar sacral plexus. Table 2 represents their origin and frequency when forming the lumbar sacral plexus in the right and left sides.

The femoral nerve stems from the contributions of the last 4 lumbar nerves, prevailing in most animals only the branches from $\mathrm{L}_{5}$ and $\mathrm{L}_{6}$ in both sides, found in $80 \%$ and $85 \%$ in the right and left sides, respectively. Analysis of the chi-square test indicates that only the arrangement $\mathrm{L}_{5} \mathrm{~L}_{6} \mathrm{~L}_{7}$ significantly differed between the sides $(\mathrm{p}<0.001)$.

Concerning the obturator nerve, we observed that it might be formed, in both sides, by the ventral roots of $\mathrm{L}_{5} \mathrm{~L}_{6}(55 \%), \mathrm{L}_{6} \mathrm{~L}_{7}(30 \%), \mathrm{L}_{4} \mathrm{~L}_{5} \mathrm{~L}_{6}(5 \%)$, or $\mathrm{L}_{5} \mathrm{~L}_{6} \mathrm{~L}_{7}(10 \%)$.

However, the ischiatic nerve in the yellow-toothed cavy stemmed from roots of $\mathrm{L}_{6} \mathrm{~L}_{7} \mathrm{~S}_{1}(60 \%)$ and $\mathrm{L}_{7} \mathrm{~S}_{1} \mathrm{~S}_{2}$ $(40 \%)$. When comparing sexes, it was found that in $80 \%$ of females the branches forming the ischiatic nerve stemmed from $\mathrm{L}_{6} \mathrm{~L}_{7} \mathrm{~S}_{1}$, while in males the most frequent they stemmed from $\mathrm{L}_{7} \mathrm{~S}_{1} \mathrm{~S}_{2}(60 \%)$.

TABLE 2: Origin and frequency of nerves comprising the lumbar sacral plexus in the right (R) and left (L) sides.

\begin{tabular}{|c|c|c|c|c|c|c|c|}
\hline \multirow{2}{*}{ Nerves } & \multicolumn{2}{|c|}{ Origin } & \multicolumn{4}{|c|}{ Absolute frequency } & \multirow{2}{*}{$\mathbf{p}$} \\
\hline & $\mathbf{R}$ & $\mathbf{L}$ & $\mathbf{R}$ & $\mathbf{L}$ & $\mathbf{R}$ & $\mathbf{L}$ & \\
\hline Femoral & $\begin{array}{c}\mathrm{L}_{4} \mathrm{~L}_{5} \mathrm{~L}_{6} \\
\mathrm{~L}_{5} \mathrm{~L}_{6} \\
\mathrm{~L}_{6} \mathrm{~L}_{7} \\
\mathrm{~L}_{5} \mathrm{~L}_{6} \mathrm{~L}_{7}\end{array}$ & $\begin{array}{c}\mathrm{L}_{4} \mathrm{~L}_{5} \mathrm{~L}_{6} \\
\mathrm{~L}_{5} \mathrm{~L}_{6} \\
\mathrm{~L}_{6} \mathrm{~L}_{7}\end{array}$ & $\begin{array}{c}1 \\
16 \\
2 \\
1\end{array}$ & $\begin{array}{c}1 \\
17 \\
2 \\
0\end{array}$ & $\begin{array}{c}5 \\
80 \\
10 \\
5\end{array}$ & $\begin{array}{c}5 \\
85 \\
10 \\
0\end{array}$ & $\begin{array}{c}0.7518 \\
0.5417 \\
0.8231 \\
0.0005^{*}\end{array}$ \\
\hline Obturator & $\begin{array}{c}\mathrm{L}_{4} \mathrm{~L}_{5} \mathrm{~L}_{6} \\
\mathrm{~L}_{5} \mathrm{~L}_{6} \\
\mathrm{~L}_{5} \mathrm{~L}_{6} \mathrm{~L}_{7} \\
\mathrm{~L}_{6} \mathrm{~L}_{7}\end{array}$ & $\begin{array}{c}\mathrm{L}_{4} \mathrm{~L}_{5} \mathrm{~L}_{6} \\
\mathrm{~L}_{5} \mathrm{~L}_{6} \\
\mathrm{~L}_{5} \mathrm{~L}_{6} \mathrm{~L}_{7} \\
\mathrm{~L}_{6} \mathrm{~L}_{7}\end{array}$ & $\begin{array}{c}1 \\
11 \\
2 \\
6\end{array}$ & $\begin{array}{c}1 \\
11 \\
2 \\
6\end{array}$ & $\begin{array}{c}5 \\
55 \\
10 \\
30\end{array}$ & $\begin{array}{c}5 \\
55 \\
10 \\
30\end{array}$ & $\begin{array}{l}0.7518 \\
0.9240 \\
0.8231 \\
0.8973\end{array}$ \\
\hline Ischiatic & $\begin{array}{l}\mathrm{L}_{6} \mathrm{~L}_{7} \mathrm{~S}_{1} \\
\mathrm{~L}_{7} \mathrm{~S}_{1} \mathrm{~S}_{2}\end{array}$ & $\begin{array}{l}\mathrm{L}_{6} \mathrm{~L}_{7} \mathrm{~S}_{1} \\
\mathrm{~L}_{7} \mathrm{~S}_{1} \mathrm{~S}_{2}\end{array}$ & $\begin{array}{c}12 \\
8\end{array}$ & $\begin{array}{c}12 \\
8\end{array}$ & $\begin{array}{l}60 \\
40\end{array}$ & $\begin{array}{l}60 \\
40\end{array}$ & $\begin{array}{l}0.9273 \\
0.9110\end{array}$ \\
\hline Cranial gluteal & $\begin{array}{c}\mathrm{L}_{7} \\
\mathrm{~L}_{7} \mathrm{~S}_{1} \\
\mathrm{~S}_{1}\end{array}$ & $\begin{array}{c}\mathrm{L}_{7} \\
\mathrm{~L}_{7} \mathrm{~S}_{1} \\
\mathrm{~S}_{1}\end{array}$ & $\begin{array}{c}14 \\
3 \\
3\end{array}$ & $\begin{array}{c}14 \\
3 \\
3\end{array}$ & $\begin{array}{l}70 \\
15 \\
15\end{array}$ & $\begin{array}{l}70 \\
15 \\
15\end{array}$ & $\begin{array}{l}0.9326 \\
0.8551 \\
0.8551\end{array}$ \\
\hline Caudal gluteal & $\begin{array}{c}\mathrm{L}_{7} \\
\mathrm{~L}_{7} \mathrm{~S}_{1} \\
\mathrm{~S}_{1}\end{array}$ & $\begin{array}{c}\mathrm{L}_{7} \\
\mathrm{~L}_{7} \mathrm{~S}_{1} \\
\mathrm{~S}_{1}\end{array}$ & $\begin{array}{l}4 \\
8 \\
8\end{array}$ & $\begin{array}{l}4 \\
9 \\
7\end{array}$ & $\begin{array}{l}20 \\
40 \\
40\end{array}$ & $\begin{array}{l}20 \\
45 \\
35\end{array}$ & $\begin{array}{l}0.8744 \\
0.3952 \\
0.3654\end{array}$ \\
\hline Pudendal & $\begin{array}{c}\mathrm{S}_{2} \\
\mathrm{~S}_{2} \mathrm{~S}_{3} \\
\mathrm{~S}_{3}\end{array}$ & $\begin{array}{c}\mathrm{S}_{2} \\
\mathrm{~S}_{2} \mathrm{~S}_{3} \\
\mathrm{~S}_{3}\end{array}$ & $\begin{array}{c}4 \\
10 \\
6\end{array}$ & $\begin{array}{c}4 \\
10 \\
6\end{array}$ & $\begin{array}{l}20 \\
50 \\
30\end{array}$ & $\begin{array}{l}20 \\
50 \\
30\end{array}$ & $\begin{array}{l}0.8744 \\
0.9203 \\
0.8973\end{array}$ \\
\hline
\end{tabular}

* Chi-square test with Yates' correction $(\mathrm{p}<0.05)$. 
In $70 \%$ of animals, the cranial gluteal nerve stemmed from $\mathrm{L}_{7}$ and, in $30 \%$ of them stemmed from $\mathrm{S}_{1}$. It was found that the caudal gluteal nerve stems from the combination of $\mathrm{L}_{7} \mathrm{~S}_{1}(45 \%), \mathrm{S}_{1}(35 \%)$, or $\mathrm{L}_{7}(20 \%)$ (Figure 5).

The pudendal nerve stemmed from the confluence of roots from $\mathrm{S}_{2} \mathrm{~S}_{3}$ in $50 \%$ of cases. It stemmed from branches of $\mathrm{S}_{2}$ or $\mathrm{S}_{3}$ (Table 2) in other animals.

FIGURE 5: Dorsal view of the lumbar sacral region in the yellowtoothed cavy showing the ischiatic nerve and cranial gluteal nerve. Scale: $1 \mathrm{~cm}$.

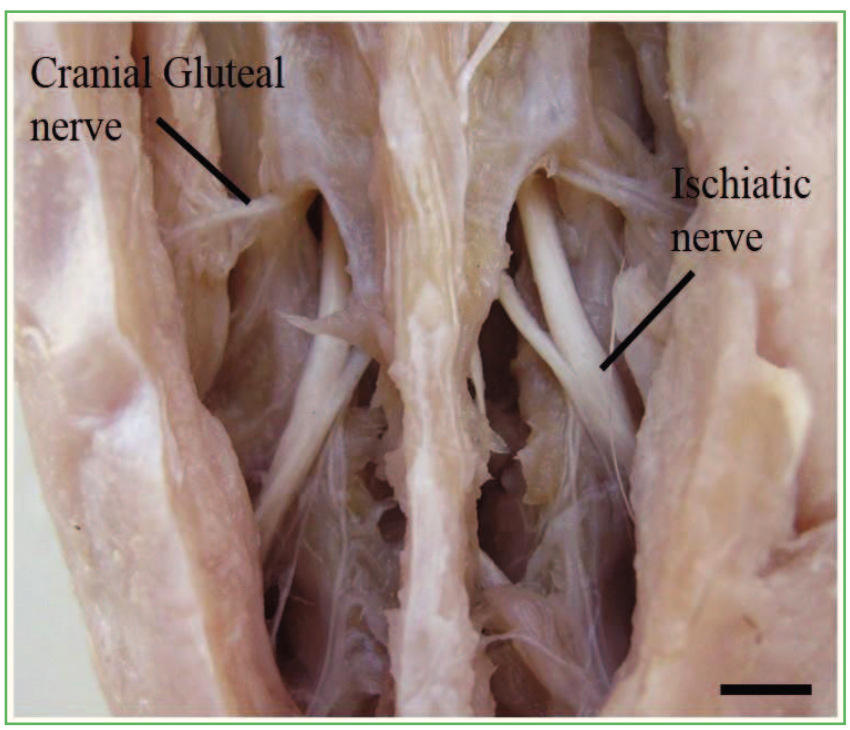

\section{Discussion}

We noticed that the results obtained in this study are related to those reported by Godinho et al. (1985) regarding domestic species, since the number of lumbar and sacral vertebrae in the yellow-toothed cavy ranged from 6 to 7 and 3 to 4 , respectively, thus, it influences the amount of spinal nerves.

Analyzing the number of lumbar and sacral vertebrae among domestic mammals, König and Liebich (2011) describe 6 or 7 lumbar and 3 sacral vertebrae for carnivores, 5 to 7 lumbar and 4 sacral vertebrae for pigs, 6 lumbar and 5 sacral vertebrae for cattle, 6 lumbar and 3 to 5 sacral vertebrae for small ruminants, and 5 to 7 lumbar and 5 sacral vertebrae for horses. Getty (1981a; 1981b) reports 6 to 7 lumbar and 4 sacral vertebrae for pigs, 7 lumbar and 3 sacral vertebrae for dogs and cats,
5 or 6 lumbar and 4 or 6 sacral vertebrae for horses, and 6 lumbar and 5 sacral vertebrae for cattle. Frandson et al. (2005) describe 6 lumbar and 5 sacral vertebrae for cattle and horses and 6 to 7 lumbar and 4 sacral vertebrae for pigs.

Lacerda et al. (2006), in studies on the lumbar sacral plexus of cavies, describe that the number of lumbar and sacral vertebrae in this species varies and the nerves from $\mathrm{S}_{4}$ did not participate in the formation of plexus, corroborating the results of this study.

The lumbosacral plexus in the yellow-toothed cavy often $(65 \%)$ stemmed from the ventral roots of $\mathrm{L}_{5} \mathrm{~L}_{6} \mathrm{~L}_{7} \mathrm{~S}_{1} \mathrm{~S}_{2} \mathrm{~S}_{3}$ (Type II), corroborating what Lacerda et al. (2006) found when studying this plexus in rock cavy. Tonini et al. (2014) found in lowland pacas that plexus stemmed from the ventral branches of the lumbar spinal nerves $\mathrm{L}_{4}, \mathrm{~L}_{5}, \mathrm{~L}_{6}$, and $\mathrm{L}_{7}$ and from the sacral spinal nerves $\mathrm{S}_{1}, \mathrm{~S}_{2}$, and $\mathrm{S}_{3}$, result also observed in yellow-toothed cavy. However, they differ from those described by Nunes and Silvino (1996) for agoutis, where plexus stemmed much frequently from the 2 last lumbar nerves and only from the first sacral nerve. Aydin et al. (2009), studying the lumbosacral plexus of porcupines (Hystrix cristata), found that it is formed by the ventral roots of the branches $\mathrm{L}_{1}, \mathrm{~L}_{2}, \mathrm{~L}_{3}, \mathrm{~L}_{4}$, and $\mathrm{S}_{1}$ and a fine branch of $\mathrm{T}_{15}$ and $\mathrm{S}_{2}$. In turn, Aydin (2010), describing the lumbosacral plexus in the red squirrel (Sciurus vulgaris), observed that it was frequently formed by $\mathrm{L}_{6}, \mathrm{~L}_{7}, \mathrm{~S}_{1}, \mathrm{~S}_{2}$, and there might be contribution of $\mathrm{L}_{4}$ and $\mathrm{L}_{5}$.

In turn, Lopes et al. (2012) reported that the lumbosacral plexus in ocelot is formed by the ventral roots $\mathrm{L}_{4}, \mathrm{~L}_{5}, \mathrm{~S}_{1}$, and $\mathrm{S}_{2}$, differing from that observed in the yellow-toothed cavy. The results found in the yellow-toothed cavy also differ from those reported by Lorenzão et al. (2012) in Cerdocyon thous and Dusicyon gymnocercus, when reporting that the lumbosacral plexus is formed by branches of $\mathrm{L}_{6}-\mathrm{S}_{2}$ and differ from what was reported by Cardoso et al. (2013), when the authors said that this plexus in the lesser anteater stemmed from $\mathrm{T}_{18}, \mathrm{~L}_{1}, \mathrm{~L}_{2}, \mathrm{~L}_{3}, \mathrm{~S}_{1}-\mathrm{S}_{5}$ and also differ from that reported by Cruz et al. (2014) for Myrmecophaga tridactyla, whose plexus is formed by the ventral roots $\mathrm{T}_{16}, \mathrm{~L}_{1}, \mathrm{~L}_{2}, \mathrm{~S}_{1}-\mathrm{S}_{5}$. 
The femoral, obturator, ischiatic, cranial gluteal, caudal gluteal, and pudendal nerves stemmed from the lumbar sacral plexus in the yellow-toothed cavy, and the presence of the ilio-hypogastric, ilio-inguinal and genito-femoral nerves was not observed in any case according to Barros et al. (2003) regarding Cebus apella, different from what was reported by Rondini et al. (2005) regarding chinchillas. Rondini et al. (2005) found that the lumbar sacral plexus in chinchillas stemmed from roots of $\mathrm{L}_{1}$ to $\mathrm{S}_{3}$ and it consisted of the ilio-hypogastric, ilio-inguinal, femoral lateral cutaneous, genito-femoral, obturator, femoral, ischiatic, pudendal, and caudal rectal nerves.

It was observed in the yellow-toothed cavy that the femoral nerve often stem from $\mathrm{L}_{5}$ and $\mathrm{L}_{6}$, but it can have variable contributions of the fourth and seventh lumbar nerve, similarly to what was reported by Oliveira et al. (2011) when studying the origin of the femoral nerve in rock cavy. These authors also report a small asymmetry in the origin of the femoral nerve between right and left antimeres, situation observed in the yellow-toothed cavy, but there was no statistically significant difference $(\mathrm{p}<0.05)$.

Rondini et al. (2005) describe in chinchillas and Tonini et al. (2014) in lowland paca that the femoral nerve stems from $\mathrm{L}_{5}$ and $\mathrm{L}_{6}$, while Castro et al. (2005) report that the femoral nerve stems from $\mathrm{L}_{3} \mathrm{~L}_{4}$ in the fur seal. However, both studies did not determine the number of lumbar and sacral vertebrae in these species. Lopes et al. (2012) identified in ocelot that the femoral nerve is formed by the ventral roots of $\mathrm{L}_{4}$, while Chrisman (1985) described that, in dogs and cats, this nerve is formed by the segments of $\mathrm{L}_{4}$ and $\mathrm{L}_{5}$. Getty (1981a) reports that this nerve stems essentially from $\mathrm{L}_{3} \mathrm{~L}_{4} \mathrm{~L}_{5}$, and it may still have a fascicle of $\mathrm{L}_{6}$ in horses. Differently from Rondini et al. (2005) and Getty (1981a), the root of $\mathrm{L}_{3}$ was not included in the formation of this nerve in the yellow-toothed cavy.

Regarding the obturator nerve, it was found that it was formed, in both sides, by the ventral roots of $\mathrm{L}_{5} \mathrm{~L}_{6}$ (55\%). Tonini et al. (2014) observed in the lowland paca that the obturator nerve derives most often from $\mathrm{L}_{6}$, but it may receive branches of $\mathrm{L}_{5}$ or $\mathrm{L}_{7}$. Miranda et al. (2007), studying bovine fetuses, reported that the obturator nerve stemmed from $\mathrm{L}_{5} \mathrm{~L}_{6} \mathrm{~S}_{1}, \mathrm{~L}_{5} \mathrm{~L}_{6}$ and $\mathrm{L}_{6} \mathrm{~S}_{1}$, obtaining symmetry between the right and left sides in all samples, corroborating the results found for the yellow-toothed cavy. Chagas et al. (2006) point out that the obturator nerve is formed by branches of $\mathrm{L}_{4}$ a $\mathrm{L}_{6}$ in pigs (Sus scrofa). Barros et al. (2003) report that its origin occurs in $\mathrm{L}_{3}, \mathrm{~L}_{4}$, and $\mathrm{L}_{5}$ in Cebus apella. In turn, Lopes et al. (2012) reported that in ocelot this nerve is formed only by $\mathrm{L}_{4}$, different from what was found in the yellow-toothed cavy.

The ischiatic nerve in the yellow-toothed cavy stemmed from roots derived from $\mathrm{L}_{6} \mathrm{~L}_{7} \mathrm{~S}_{1}$ and $\mathrm{L}_{7} \mathrm{~S}_{1} \mathrm{~S}_{2}$. Rondini et al. (2005) and Lacerda et al. (2006), studying the lumbar sacral plexus in chinchillas and cavies, respectively, found that especially the roots from $\mathrm{L}_{6} \mathrm{~L}_{7} \mathrm{~S}_{1}$ contribute to the formation of the ischiatic nerve in these animals, according to the results found for the yellow-toothed cavy. Santos et al. (2006), studying the origin of the ischiatic nerve in rocky cavies, and Tonini et al. (2014) in lowland paca, found that it stemmed from the ventral roots of $\mathrm{L}_{7} \mathrm{~S}_{1} \mathrm{~S}_{2}$, what was observed in $40 \%$ of the samples under study. Lopes et al. (2012) reported that in ocelot, the ischiatic nerve is formed by the last lumbar nerve roots $\left(\mathrm{L}_{5}\right)$ and the first sacral $\left(\mathrm{S}_{1}\right)$. Aydin (2010) in Sciurus vulgaris and Guimarães et al. (2005) in house cats reported that, differently from the yellow-toothed cavy, the ischiatic nerve is formed by the ventral roots of $\mathrm{L}_{6} \mathrm{~L}_{7} \mathrm{~S}_{1} \mathrm{~S}_{2}$. Getty (1981a) points out that the ischiatic nerve stems from the last lumbar nerve and the first and second sacral components of the lumbar sacral trunk. In turn, in T. tetradactyla (CARDOSO et al., 2013) it was derived from $\mathrm{L}_{3}, \mathrm{~S}_{1}, \mathrm{~S}_{2}$, and $\mathrm{S}_{3}$, a situation not observed in the yellow-toothed cavy.

The cranial gluteal nerve stemmed from $\mathrm{L}_{7}$, similarly to the results described by Lacerda et al. (2006). In turn, Aydin et al. (2009) and Tonini et al. (2014), differently from what was observed in the yellow-toothed cavy, reported that the cranial gluteal nerve originates from $\mathrm{L}_{3}$ and $\mathrm{L}_{4}$ and $\mathrm{L}_{6}$ and $\mathrm{L}_{7}$, respectively. Chrisman (1985) reports that, in dogs and cats, the cranial gluteal nerve is formed by the segments $\mathrm{L}_{6}$ and $\mathrm{L}_{7}$ of the spinal cord. Getty (1981a; 1981b) reports that the cranial gluteal nerve stems from $\mathrm{L}_{6} \mathrm{~L}_{7}$ in cats. It seems to stem from $\mathrm{L}_{5} \mathrm{~L}_{6} \mathrm{~S}_{1}$ in pigs, and it usually stems from $\mathrm{L}_{6} \mathrm{~L}_{7}$ in dogs. It may have contributions of $\mathrm{S}_{1}, \mathrm{~L}_{6}$ and $\mathrm{S}_{1}$ in ruminants and 
the last lumbar and first sacral nerves in horses. The fifth lumbar root is commonly found forming this nerve. On the other hand, Lopes et al. (2012) reports that in ocelot this nerve originates from the ischiatic nerve.

For the caudal gluteal nerve, findings point out that it often stems from $\mathrm{L}_{7} \mathrm{~S}_{1}$. Chrisman (1985) and Lacerda et al. (2006) observed that it stems only from $L_{7}$, something found in $20 \%$ of samples under study. Tonini et al. (2014) observed in lowland paca that the caudal gluteal nerve was formed only by $\mathrm{L}_{7}$ or, in some cases, by $\mathrm{L}_{7} \mathrm{~S}_{1}$. Getty (1981a; 1981b) describes this nerve as stemming from $\mathrm{L}_{6} \mathrm{~L}_{7} \mathrm{~S}_{1}$ in dogs and cats, from $\mathrm{L}_{5} \mathrm{~L}_{6} \mathrm{~S}_{1} \mathrm{~S}_{2}$ in pigs, with inconstant contributions of the fourth and fifth lumbar nerves, from $\mathrm{S}_{1} \mathrm{~S}_{2}$ and, occasionally, $\mathrm{S}_{3}$ in ruminants, and from the sacral roots of the lumbar sacral plexus in horses.

The pudendal nerve stems from the confluence of the roots from $\mathrm{S}_{2} \mathrm{~S}_{3}$, according to what was found by Rondini et al. (2005), Lacerda et al. (2006), and Tonini et al. (2014) when studying chinchillas, cavies, and lowland paca. Getty (1981a) reports that this nerve is formed by the ventral branch of the third sacral nerve, with variable contribution of $\mathrm{S}_{2}$ and $\mathrm{S}_{4}$ in cattle, goats, and horses. Aydin et al. (2009) observed that in porcupines this nerve was formed only by $\mathrm{S}_{2}$. In studies with lesser anteater, Cardoso et al. (2013) reported that the pudendal nerve is formed by roots of $\mathrm{S}_{3} \mathrm{~S}_{4}$ or $\mathrm{S}_{4} \mathrm{~S}_{5}$. In turn, Cruz et al. (2014) describe in the Myrmecophaga tridactyla that this nerve originates from $\mathrm{S}_{4} \mathrm{~S}_{5}$, differing from the yellow-toothed cavy.

Therefore, the ventral roots of the fourth, fifth, sixth, and seventh lumbar nerves and the three first sacral nerves contribute to the formation of the lumbosacral plexus in this species, and it is a plexus type II $\left(\mathrm{L}_{5} \mathrm{~L}_{6} \mathrm{~L}_{7} \mathrm{~S}_{1} \mathrm{~S}_{2} \mathrm{~S}_{3}\right)$ and the femoral, obturator, ischiatic, cranial gluteal, caudal gluteal, and the pudendal nerves participate in the lumbosacral plexus of the yellow-toothed cavy. The lumbosacral plexus of the yellow-toothed cavy showed to be similar to the other caviomorphs, such as the rocky cavy, something which seems to be a pattern for this family. The results found are relevant for clinical and surgical care and anesthesiology regarding these wild species, and they also provide data for comparative anatomy.

\section{References}

AYDIN, A. The spinal nerves that constitute the plexus lumbosacrales of the red squirrel (Sciurus vulgaris). Veterinarni Medicina, Praga, v. 55, n. 4, p. 183-186, 2010.

AYDIN, A.; DINC, G.; YILMAZ, S. The spinal nerves that constitute the plexus lumbosacrales of porcupines (Hystrix cristata). Veterinarni Medicina, Praga, v. 54, n. 4, p. 194-197, 2009.

BARROS, R. A.; PRADA, I. L. S.; SILVA, Z; RIBEIRO, A. R.; SILVA, D. C. O. Constituição do plexo lombar em macaco Cebus apella. Brazilian Journal of Veterinary Research and Animal Science, São Paulo, v. 40, n. 5, p. 373-381, 2003.

CARDOSO, J. R.; SOUZA, P. R.; CRUZ, V. S.; BENETTI, E. J.; BRITO E SILVA, M. S.; MOREIRA, P. C. CARDOSO, A. A. L.; MARTINS, A. K.; ABREU, T.; SIMÕES, K.; GUIMARÃES, F. R. Estudo anatômico do plexo lombossacral de Tamandua tetradactyla. Arquivo Brasileiro de Medicina Veterinária e Zootecnia, Belo Horizonte, v. 65, n. 6, p. 1720-1728, 2013.

CASTRO, T. F.; SOUZA, D. A. S.; FRANCESCHI, R. C.; DUMMER, R. J.; PEREIRA, M. A. M.; SILVA FILHO, R. P. Sistematização da inervação lombo-sacral em Arctocephalus australis. In: CONGRESSO DE INICIAÇÃO CIENTÍFICA, XIV, 2005, Pelotas. Resumos... Pelotas, UFPEL, 2005. Versão eletrônica.

CHAGAS, R. G.; DRUMMOND, S. S.; CARNEIRO E SILVA, F. O.; EURIDES, D.; ALVES, E. C. M.; MIRANDA, R. L. Origem e distribuição do nervo obturatório em suínos (Sus scrofa domesticus - Linnaeus, 1758) da linhagem ag-1050. Arquivo de Ciências Veterinárias e Zoologia da UNIPAR, Umuarama, v. 9, n. 1, p. 15-20, 2006

CHRISMAN, C. L. Neurologia dos pequenos animais. São Paulo: Editora Roca, 1985. 432 p.

CRUZ, V. S.; CARDOSO, J. R.; ARAÚJO, L. B. M.; SOUZA, P. B.; BORGES, N. C.; ARAÚJO, E. G.. Aspectos anatômicos do plexo lombossacral de Myrmecophaga tridactyla (Linnaeus, 1758). Bioscience Journal, Uberlândia, v. 30, n. 1, p. 235-244, 2014.

DYCE, K. M.; SACK, W. O.; WENSING, C. J. Tratado de anatomia veterinária. 3 ed. Rio de Janeiro: Editora Elsevier, 2004. $813 \mathrm{p}$.

FRANDSON, R. D.; WILKE, W. L.; FAILS, A. D. Anatomia e fisiologia dos animais da fazenda. 6. ed. Rio de Janeiro: Editora Guanabara Koogan, 2005. 454 p.

GETTY, R. Anatomia dos animais domésticos. Vol. 1. 5. ed. Rio de Janeiro: Editora Interamericana, 1981a. 1134 p.

GETTY, R. Anatomia dos animais domésticos. Vol. 2. 5. ed. Rio de Janeiro: Editora Interamericana, 1981b. 1986 p.

GODINHO, H. P.; NASCIMENTO, J. F.; CARDOSO, F. M. Anatomia dos ruminantes domésticos. Belo Horizonte: Editora Instituto de Ciências Biológicas da UFMG, 1985. 126 p.

GUIMARÃES, G. C.; MACHADO, M. R. F.; SANTOS, A. L. Q.; VIEIRA, L. G.; SOUZA, A. G.; SILVA, J. M. M.; KAMINISHI, A. P. S. Origem e distribuição do nervo isquiático no gato doméstico (Felis catus domesticus, Linnaeus, 1758). Bioscience Journal, Uberaba, v. 21, n. 1, p. 189-195, 2005.

KÖNIG, H. E.; LIEBICH, H. G. Anatomia dos animais domésticos: texto e atlas colorido. Porto Alegre: Artmed, 2011. $788 \mathrm{p}$. 
LACERDA, P. M. O.; MOURA, C. E. B.; MIGLINO, M. A.; OLIVEIRA, M. F.; ALBUQUERQUE, J. F. G. Origem do plexo lombossacral de mocó (Kerodon rupestris). Brazilian Journal of Veterinary Research and Animal Science, São Paulo, v. 43, n. 5, p. 620-628, 2006

LOPES, J. A.; FÉ, L. C. M.; LIMA, A. R.; PEREIRA, L. C.; BRANCO, E. Morfologia do plexo lombossacral da jaguatirica (Leopardus pardalis). Biotemas, Florianópolis, v. 25, n.4, p.215220, 2012.

LORENZÃO, C. J.; ZIMPEL, A. V.; NOVAKOSKI, E.; TEICHMANN, C. E.; MARTINEZ-PEREIRA, M. A. Dados preliminares sobre a formação do plexo lombossacral em graxaimdo-mato (Cerdocyon thous) e graxaim-do-campo (Dusicyon gymnocercus). In: SEMINÁRIO INTERINSTITUCIONAL DE ENSINO, PESQUISA E EXTENSÃO, XVII, 2012, Cruz Alta. Resumos... Cruz Alta: UNICRUZ, 2012. Versão eletrônica.

MENDES, B. V. Plantas e animais para o Nordeste. Rio de Janeiro: Editora Globo, 1945. 167 p.

MIRANDA, R. L.; SILVA, F. O. C.; SEVERINO, R. S.; DRUMMOND, S. S.; GONÇALVEZ, R. C. Origens e distribuições dos nervos obturatórios em fetos fêmeas de bovinos azebuados. Bioscience Journal, Uberaba, v. 23, n. 4, p. 120-127, 2007.
NUNES, L. C.; SILVINO, M. J. Formação do plexo lombossacral em cutia dourada (Dasyprocta aguti). In: CONGRESSO BRASILEIRO DE ANATOMIA, 17, 1996, Fortaleza. Resumos... Fortaleza: CBA, 1996. p. 139.

OLIVEIRA, G. B.; ALBUQUERQUE, J. F. G.; RODRIGUES, M. N.; PAIVA, A. L. C.; MOURA, C. E. B.; MIGLINO, M. A.; OLIVEIRA, M. F. Origem e distribuição do nervo femoral do mocó, Kerodon rupestris (Cavidae). Pesquisa Veterinária Brasileira, Seropédica, v. 31. Supl. 1, p. 84-88, 2011.

RONDINI, B. T.; GAMBA, C. O.; PEREIRA, R. L.; WULFF, M. L.; PEREIRA, M. A. M.; RICKES, E. M. Sistematização dos territórios nervosos do plexo lombo-sacral em Chinchilla lanigera. In: CONGRESSO DE INICIAÇÃO CIENTÍFICA, XIV, 2005, Pelotas. Resumos... Pelotas: UFPEL, 2005. Versão eletrônica.

SANTOS, R. C.; AlBUQUeRQUE, J. F. G.; SILVA, M. C. V.; MOURA, C. E. B.; CHAGAS, R. S. N.; BARBOSA, R. R.; MIGLINO, M. A. Anatomia do nervo isquiático em mocós (Kerodon rupestris WIED, 1820) aplicada à clínica de animais silvestres. Brazilian Journal of Veterinary Research and Animal Science, São Paulo, v. 43, n. 5, p. 647-653, 2006.

TONINI, M. G. O.; SASAHARA, T. H. C.; LEAL, L. M.; MACHADO, M. R. F. Origem e distribuição do plexo lombossacral da paca (Cuniculus paca, Linnaeus 1766). Biotemas, Florianópolis, v. 27, n. 2, p. 157-162, 2014. 